\title{
Greener and efficient one-pot synthesis of novel multi-substituted 3-(4,5-diphenyl- $1 H$-imidazol-2-yl)- $1 H$-indole derivatives by using recyclable catalyst under microwave irradiation
}

\author{
Narendra Nirwan ${ }^{a^{*}}$ and Chandresh Pareek ${ }^{\mathrm{b}}$
}

${ }^{a}$ Department of Chemistry, Govt. Girls College, Ajmer, Rajasthan, India

${ }^{b}$ Department of Chemistry, MBD, Govt. Govind Guru Trible University Banswara, India

\begin{tabular}{l} 
C H R O N I C L E \\
\hline Article history: \\
Received October 18, 2020 \\
Received in revised form \\
January 28, 2021 \\
Accepted February 14, 2021 \\
Available online \\
February 14, 2021 \\
\hline Keywords: \\
Indolylimidazole \\
Green synthesis \\
Reusable Catalyst \\
Amberlyst A-15, 3-(4,5-Diphenyl- \\
1H-imidazol-2-yl)-1H-indole
\end{tabular}

\begin{abstract}
A B S T R A C T
The novel class of multi-substituted indolylimidazole derivatives series substituted 3-(4,5diphenyl- $1 H$-imidazol-2-yl)- $1 H$-indole and substituted 5-bromo-3-(4,5-diphenyl- $1 H$ imidazol-2-yl)- $1 H$-indole was synthesized utilising a green and efficient one-pot four components condensation of indole-3-carbaldehyde, benzil, ammonium acetate and various amines under microwave irradiation using Amberlyst A-15 as a recyclable catalyst. The catalyst Amberlyst A-15 has recovered from the reaction mixture and reused repeatedly for the next reaction. The key advantage of this process involves eco-friendly, very short reaction time, cost-effectiveness with the reusability of catalyst, easy workup, and purification of the product with excellent yields. FTIR, ${ }^{1} \mathrm{HNMR}$ and Mass spectrometric studies analyzed and established the structures of all newly synthesized compounds.
\end{abstract}

(C) 2021 Growing Science Ltd. All rights reserved.

\section{Introduction}

Natural and synthesized indolylimidazole compounds that contain both indole and imidazole rings play an important role in medicinal science because of their wide spectrum of biological and pharmacological activities. ${ }^{1}$ The 3 -substituted indole alkaloids with additional imidazole ring and indole alkaloid with additional multi-substituted imidazole ring show most biological activities, and their applications are very advantageous in various fields of science.

Indolylimidazole structure resembling natural compounds such as Topsentin was first reported in 1987 and isolated from marine sponges. ${ }^{2-5}$ These Topsentin and its derivatives showed different biological activities such as antibacterial, ${ }^{6}$ antiviral, ${ }^{7}$ antitumor, ${ }^{7-9}$ and anti-inflammatory. ${ }^{10-11}$ Nortopsentins A-C, topentin and bromotopsentin isolated from the deep-sea sponge Spongosorites ruetzleri and showed in vitro cytotoxicity against $\mathrm{P} 388$ cells and antifungal activity against Candida

* Corresponding author.

E-mail address: drnirwann@gmail.com (N. Nirwan)

(C) 2021 Growing Science Ltd. All rights reserved. doi: $10.5267 /$ j.ccl.2021.2.002 
Albicans. ${ }^{12}$ Nortopsentin-A exhibited antiplasmodial activity and inhibited parasite growth at the trophozoite stage at submicromolar 50\% inhibitory concentrations (IC50). ${ }^{13}$ Nortopsentins-D and $N$ methyl substituted Nortopsentin derivatives also showed cytotoxicity against P388 cells. ${ }^{14}$ Discodermindole, ${ }^{15}$ 6-Hydroxydiscodermindole ${ }^{16}$ and 2-(Dimethylamino)-5-(1H-indol-3-yl)-4Himidazol-4-one ${ }^{17}$ have been isolated from the Bahama sponge Discodermia polydiscus and exhibited cytotoxicity against murine tumor cells. Trachycladindole A-G compounds are the product of southern Australian marine sponge Trachycladuslae vispirulifer and displayed promising selective cytotoxicity against a panel of human cancer cell lines. ${ }^{18}$ Rhopaladins A-D compounds have been isolated from Okinawan tunicate Rhopalaea sp. in 1998. These compounds were reported as an antibacterial agent against Sarcinalutea, Corynebacterium xerosis, and showed inhibiting activity against cyclindependent kinase-4 and c-erb $\beta-2$ kinase. ${ }^{19}$ Indolylimidazole skeleton containing some natural compounds have also been reported as anti-depressant agent, ${ }^{20}$ protein kinase $\mathrm{C}$ inhibitor, ${ }^{21,22}$ interleukin 6-production inhibitor, ${ }^{23}$ Flt-1and topoisomerase inhibitor, ${ }^{24}$ antibiotic and antitumor agent. $^{25}$

Due to most bioactivities of indolylimidazole, the field of indolylimidazole always attracted chemists for the synthesis. Indolylimidazole frame containing synthesized compounds also have shown various biological and pharmacological activities such as radio-sensitizer against HT-29 cell line, ${ }^{26}$ cytotoxicity, ${ }^{27}$ MRSA PK inhibitor, ${ }^{28}$ antibiotic and antitumor agent, ${ }^{29}$ antibacterial, ${ }^{30,31}$ antimicrobial, ${ }^{32,33}$ antifungal, ${ }^{33}$ anti-urease, ${ }^{33,34}$ antioxidant, ${ }^{34,35}$ phosphodiesterase inhibitor, ${ }^{36}$ antiinflammatory, analgesic and antipyretic agents. ${ }^{37,38}$ Therefore, there is a strong demand for a simple, highly efficient, environment-friendly and versatile method for the synthesis of substituted indolylimidazole derivatives for their great importance.

In recent years, the substituted indolylimidazole derivatives have been synthesized and reported, in the presence of a different catalyst such as $\mathrm{Zn}^{2+}$ at $\mathrm{KSF},{ }^{29} \mathrm{SO}_{4}{ }^{2-} / \mathrm{Y}_{2} \mathrm{O}_{3},{ }^{32}$ acetic acid, ${ }^{33,34,39-42}$ acetic acid in the presence of microwave, ${ }^{43}$ strong protic acid $\mathrm{HNO}_{3} @$ nano $\mathrm{SiO}_{2}$ at $100^{\circ} \mathrm{C},{ }^{44}$ polymeric quaternary ammonium azide (QN3), ${ }^{45}$ triphenyl (propyl-3-sulphonyl)phosphonium toluene sulfonate. ${ }^{46}$ Multi-step reaction methods have also been reported for the synthesis of indolylimidazole derivatives in the presence of different conditions and catalysts such as selenium dioxide and ammonium acetate, ${ }^{36}$ aluminium chloride and reflux in the presence of acetic acid, ${ }^{37,38}$ trimethyl phosphine and microwave irradiation, ${ }^{47}$ heat and acyl chloride. ${ }^{48}$ Although some of these methods are efficient from the synthetic chemist's point of view. Many of the synthesis protocols for indolylimidazole derivatives that have been reported above sustain from one or more drawbacks, such as severe reactions, low yields, blend of products, spare of chemicals, extreme thermal conditions, elongated reaction time, multi-step reaction, use of solvents, use of fatal and usually classy and excessive acid catalysts.

\section{Result and Discussion}

In this paper, an efficient, green, and eco-friendly one-pot multi-component condensation method has been developed for the synthesis of indolylimidazole derivatives (2a-2h) and (3a-3b) by using Amberlyst A-15 as an effective, reusable catalyst under microwave irradiation [Scheme $\mathbf{1}$ and Scheme 2]. The 3-(1-substituted-4,5-diphenyl-1H-imidazol-2-yl)-1H-indole derivatives (2a-2h) were synthesized by one-pot four components condensation of $1 \mathrm{H}$-indole-3-carbaldehyde, benzil, NH4OAc, substituted-amine under microwave irradiation using Amberlyst A-15 as a recyclable catalyst.

The 5-bromo-3-(1-substituted-4,5-diphenyl-1 $H$-imidazol-2-yl)- $1 H$-indole derivatives (3a-3b) were synthesized by one-pot four components condensation of 5-bromoindol-3-carbaldehyde, benzil, $\mathrm{NH}_{4} \mathrm{OAc}$ and substituted-amine under microwave irradiation using Amberlyst A-15 as a recyclable catalyst [Scheme 2]. 


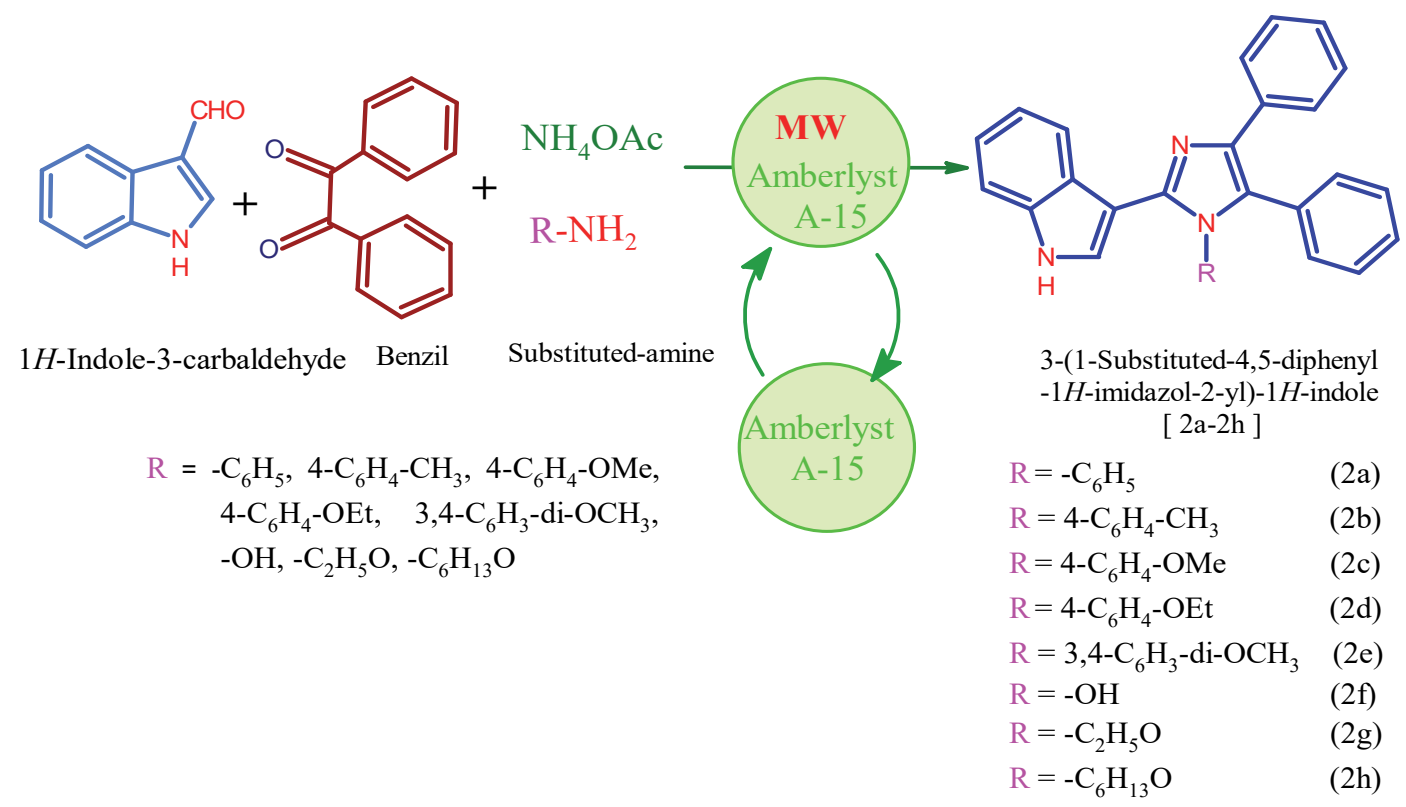

Scheme 1. Synthesis of 3-(1-substituted-4,5-diphenyl-1H-imidazol-2-yl)-1H-indole derivatives

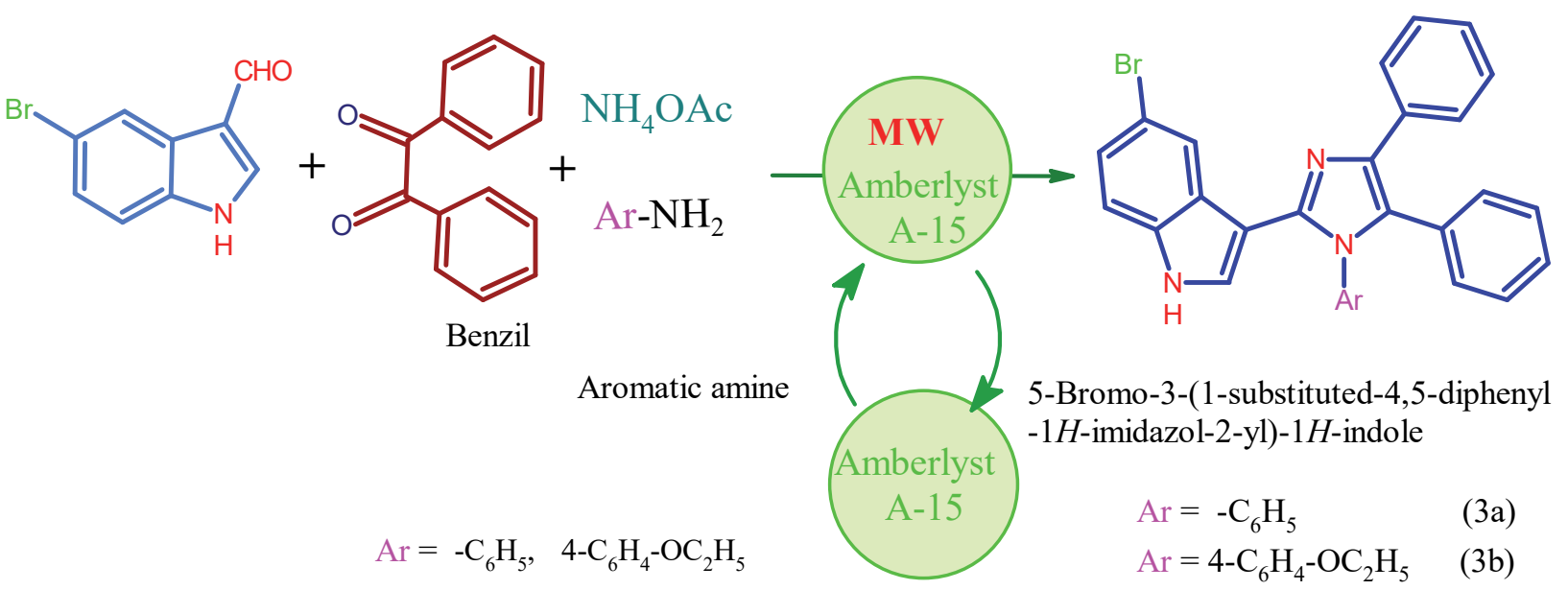

Scheme 2. Synthesis of 5-Bromo-3-(1-substituted-4,5-diphenyl-1 $H$-imidazol-2-yl)- $1 H$-indole derivatives

The synthesized molecules (2a-2h) and (3a-3b) were identified by using FTIR, ${ }^{1} \mathrm{HNMR}$ and Mass spectrometric studies. These indolylimidazole compounds have been obtained in excellent yields with shorter reaction times. Table 1 and Table 2 showed the structure of new molecules with yields percentage and reaction time. The products (2a-2d) were achieved in out-of-sight yield whereas those replaced by Bromine also produced in wonderful percentage. Data of Both Table 1 and Table 2 is under our presumption that the use of Amberlyst-A-15 provides better yield in a shorter period. The purity of synthesized compounds has been confirmed by elemental analysis and described in the experimental section.

All the compounds give an absorption in $3450-3386 \mathrm{~cm}^{-1}$ due to N-H starching of indole in FT-IR spectra. The absorption of $1673-1611 \mathrm{~cm}^{-1}$ due to aromatic $\mathrm{C}=\mathrm{N}$ function. The absorption of $3688-3644$ $\mathrm{cm}^{-1}$ (str.) 1444-1414 $\mathrm{cm}^{-1}$ (def.-ip) and 641-635 (def.-oop) due to O-H group (2f-2h). The compounds $\mathbf{3 a}$ and $\mathbf{3 b}$ give an absorption in $580 \mathrm{~cm}^{-1}$ due to $\mathrm{C}-\mathrm{Br}$ function. The absence of amine and carbonyl group in FT-IR range supported the condensation of the new compounds. 
All the compounds exhibited a singlet in $\delta=12.463$ to $11.135 \mathrm{ppm}$ region due to N-H proton of indole in the ${ }^{1} \mathrm{H}$ NMR spectra. The multiplat was observed at $\delta=7.627$ to $7.159 \mathrm{ppm}$ due to aromatic protons of benzene ring in all compounds. A singlet was observed at $\delta=14.956$ to $11.840 \mathrm{ppm}$ due to hydroxy protons in $\mathbf{2 f - 2 h}$. The mass spectra showed molecular ion peak, which are concorded with molecular formula.

Table. 1. Synthesis of 3-(1-substituted-4,5-diphenyl-1 $H$-imidazol-2-yl)-1H-indole derivatives (2a-2h)

\begin{tabular}{|c|c|c|c|c|c|c|}
\hline Entry & Carbaldehyde & Substituted-amine & Products & $\begin{array}{l}\text { Reaction Time } \\
\text { (Min.) }\end{array}$ & $\begin{array}{l}\text { Yield } \\
\text { (in \%) }\end{array}$ & M.Pt. $\left({ }^{\circ} \mathrm{C}\right)$ \\
\hline $2 a$ & & & & 12 & 94 & $235-236$ \\
\hline $2 b$ & & & & 12 & 93 & $238-239$ \\
\hline $2 \mathrm{c}$ & $\mathrm{CHO}$ & & & 10 & 96 & $242-243$ \\
\hline $2 \mathrm{~d}$ & & & & 9 & 97 & $207-209$ \\
\hline $2 \mathrm{e}$ & & & & 10 & 83 & $244-246$ \\
\hline $2 \mathrm{f}$ & & & & 14 & 80 & 190-192 \\
\hline
\end{tabular}




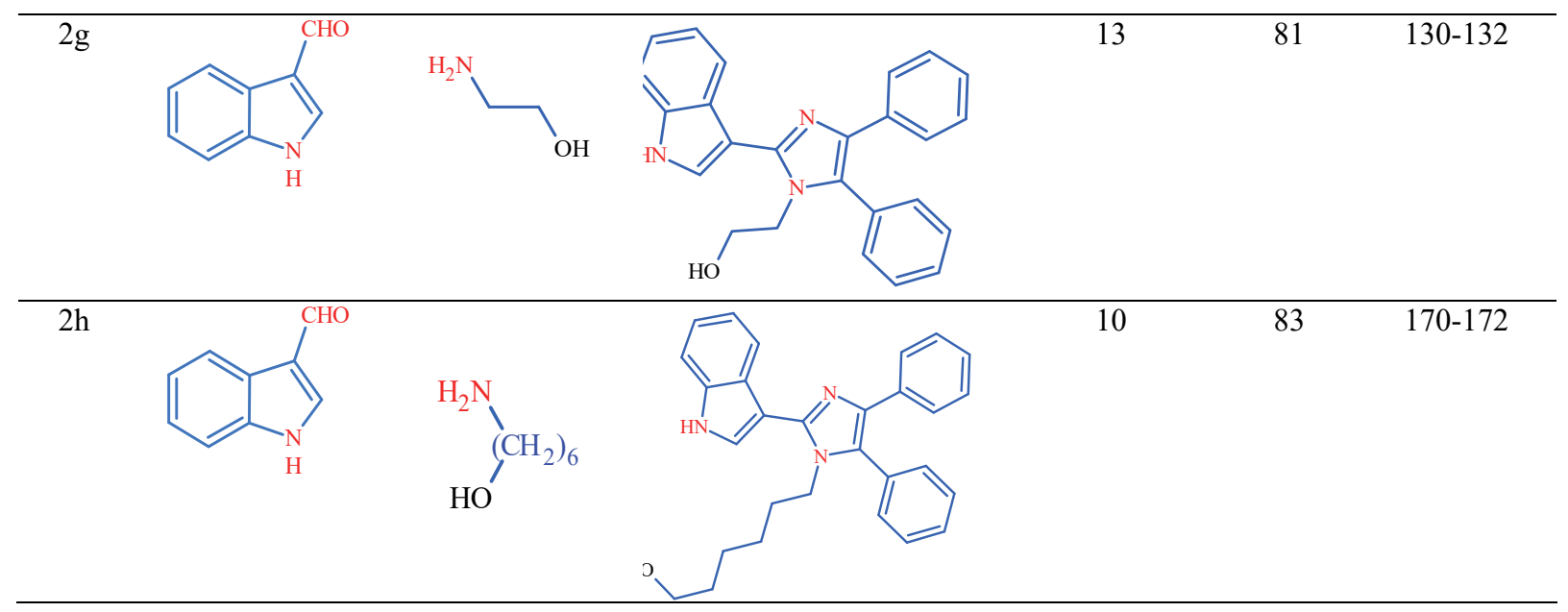

Table. 2. Synthesis of 5-Bromo-3-(1-substituted-4,5-diphenyl-1H-imidazol-2-yl)-1H-indole derivatives $(3 a-3 b)$

Entry Carbaldehyde substituted-amine

Some of these types of compounds have been synthesized and reported in the presence of different catalysts. However, reported methods suffer from several drawbacks such as drastic reaction conditions, wastes of catalyst and solvent, difficulty to handle, longer reaction time, tedious workup, and low yields. All such drawbacks are overcome in the present procedure by using recyclable Amberlyst A-15, which is easy to handle with shorter reaction time and uncomplicated workup procedure. Present work has been compared with the reported method shown in Table 3.

Table. 3. Comparison of Amberlyst A-15 with other catalysts

\begin{tabular}{cccccc}
\hline S.No. & Catalyst & Condition & Time $(\mathrm{min})$ & $\%$ Yield $^{\mathrm{a}}$ & References \\
\hline 1 & $\mathrm{Zn}^{2+} @ \mathrm{KSF}$ & $\mathrm{EtOH}$ & 35 & 78 & 29 \\
\hline 2 & $\mathrm{HNO}_{3} @$ nano $\mathrm{SiO}_{3}$ & $100^{\circ} \mathrm{C}$ & 330 & 74 & 43 \\
\hline 3 & $\mathrm{Amberlyst} \mathrm{A-15}$ & $\mathrm{MW}$ & 8 & 97 & Present work \\
\hline
\end{tabular}

${ }^{a}$ Isolated yields, comparison for module reaction of compound $2 \mathrm{c}$. 
The data in Table 3 depicts that using Amberlyst A-15 in combination with the microwave not only provides a greener and non-corrosive path but also a remarkable yield. We have achieved an excellent yield percentage with shorter reaction time in the present work as compared to reported methods. The catalyst Amberlyst A-15 was recycled for the same reaction repeatedly and found that Amberlyst A-15 could be reused for seven cycles with negligible loss of their activity [Fig. 1].

\section{Conclusion}

In summary, we have presented an efficient, mild, and rapid approach for the synthesis of novel multi-substituted indolylimidazole derivatives through one-pot condensation of a representative benzil with various substituted-amine, $1 H$-indole-3-carbaldehyde, ammonium acetate and using Amberlyst A-15 as a new and highly effective catalyst under solvent-free and microwave conditions. These indolylimidazole compounds have been obtained in excellent yields with shorter reaction times. The products (2a-2d) were achieved in out-of-sight yield whereas those replaced by Bromine also produced in wonderful percentage in 3a-3b. Non-corrosiveness, secured with low waste, shorter reaction time with high yields, and environmentally friendly are some advantages of this method. Amberlyst A-15 was a recyclable catalyst and easy to handle. This catalyst could be reused in the next reactions with negligible loss of their activity.

\section{Acknowledgment}

One author Narendra Nirwan is thankful to the Department of Chemistry, S.D. Government College, Beawar, India, for providing research facilities. The author is also thankful to Sapala Organics Pvt. Ltd., Hyderabad, India, for the spectral and analytical data. The authors are also grateful to Dr. G.S. Chauhan, Deputy Secretary, UGC, Bhopal for his help and motivation and to UGC-CSIR for granting TRF to him.

\section{Experimental}

\subsection{Materials and methods}

A microwave oven (IFB, 23BC4, $1400 \mathrm{~W}$ ) was used for synthesis. The melting point of products was measured by the use of an open capillary method. IR spectra were obtained in $\mathrm{KBr}$ by Jasco FTIR-4100 spectrometer. ${ }^{1} \mathrm{HNMR}$ spectra were recorded in DMSO with TMS as the internal reference on JEOL - $400 \mathrm{MHz}$ NMR spectrometer with multiple probe facility (AL-400). The mass spectra were recorded on LCMS SQD-2 with H Class UPLC instrument. All the chemicals and reagents used were procured from MERCK and Ranbaxy.

\subsection{General procedure}

Microwave irradiation (MW) was used for the synthesis of 2,4,5-triphenyl- $1 H$-imidazole derivatives by condensation of substituted-benzaldehyde, benzil, ammonium acetate and substitutedamine in the presence of Amberlyst A-15 catalyst. ${ }^{49-51}$

The above techniques have been employed for preparing simple imidazoles without indole ring. After some modifications, this technique was utilized for the synthesis of indolylimidazoles that contain both indole and imidazole ring under MW treatment using Amberlyst A-15 as a recyclable catalyst.

\subsubsection{Synthesis of 3-(1-substituted-4,5-diphenyl-1H-imidazol-2-yl)-1H-indole derivatives(2a-2h)}

A mixture of $1 H$-indole-3-carbaldehyde $(1 \mathrm{mmol})$, benzil $(1 \mathrm{mmol}), \mathrm{NH}_{4} \mathrm{OAc}(1 \mathrm{mmol})$, substituted-amine $(1 \mathrm{mmol})$ and Amberlyst A-15 (0.12g) was taken into $50 \mathrm{~mL}$ borosil beaker and irradiated with microwave for 8-15 minutes at almost constant temperature $80^{\circ} \mathrm{C}$. Thin-layer chromatography (ethyl acetate: petroleum ether 1:9) technique was used to monitor the headway of the reaction where Silica gel G-60 as a stationary phase. After completion, the reaction mixture was brought to room temperature and added dichloromethane. The solid Amberlyst A-15 was filtered and washed

several times with dichloromethane. Pure Amberlyst A-15 was dried at $80^{\circ} \mathrm{C}$ and reused again for the 
next reaction. The organic layer was extracted with water and dried by anhydrous $\mathrm{Na}_{2} \mathrm{SO}_{4}$ until the $\mathrm{Na}_{2} \mathrm{SO}_{4}$ swirls freely in the flask. The filtrate was then purposive by vacuum. The prepared products were washed first with dichloromethane then recrystallized with cold ethanol and dried. The purity of the obtained compound (2a-2h) was checked by TLC besides microanalysis.

\subsubsection{Synthesis of 5-Bromo-3-(1-substituted-4,5-diphenyl-1H-imidazol-2-yl)-1H-indole derivatives} $(3 a-3 b)$

The 5-Bromo-3-(1-substituted-4,5-diphenyl-1 $H$-imidazol-2-yl)-1 $H$-indole derivatives (3a-3b) were prepared by a similar procedure using 5-bromoindol-3-carbaldehyde (1 mmol), benzil (1 mmol), $\mathrm{NH}_{4} \mathrm{OAc}(1 \mathrm{mmol})$ and substituted-amine $(1 \mathrm{mmol})$.

\subsection{Recyclability of the catalyst}

To explore the recyclability of the catalyst, the Amberlyst A-15 was used repeatedly for the same reaction. The relation between the number of cycles of the reaction and recyclability in terms of yield of the catalyst is presented in Fig. 1. It is concluded that Amberlyst A-15 could be reused for seven cycles with negligible loss of their activity.

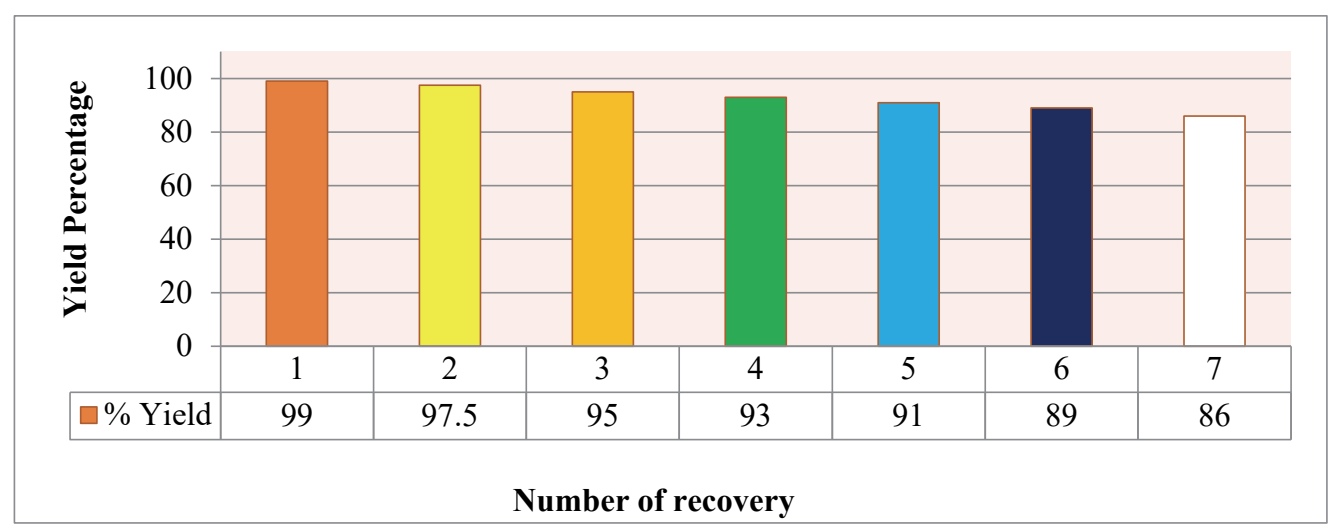

Fig. 1. Amberlyst A-15 recovery yield percentage for framework reaction

\subsection{Physical and spectral data}

\section{Key diagnostic signals in Bold text}

\section{3-(1-(4-Methylphenyl)-4,5-diphenyl-1H-imidazol-2-yl)-1H-indole (2b)}

Colorless solid, Anal.: (Calcd): C (84.68\%), H (5.45\%), N (9.87\%), (Found): C (84.70\%), H (5.43\%), N (9.85\%). FTIR (KBr, cm-1): Vmax: 3418, 3125, 3091, 2945, 1625, 1600, 1595, 1570, 1495, 1440 , 1420, 1394, 1242, 1050, 815, 774, 760, 692. ${ }^{1} \mathrm{HNMR}$ (400 MHz, DMSO-d6): 11.754 (s, 1H, indole); $8.512(\mathrm{~s}, 1 \mathrm{H}) ; 8.420(\mathrm{~d}, 1 \mathrm{H}, \mathrm{J}=7.4 \mathrm{~Hz}) ; 7.807(\mathrm{t}, 1 \mathrm{H} . \mathrm{J}=7.4 \mathrm{~Hz}) ; 7.651(\mathrm{~d}, 1 \mathrm{H}, \mathrm{J}=3.6 \mathrm{~Hz}) ; 7.579$ (t, $1 \mathrm{H}, \mathrm{J}=3.7 \mathrm{~Hz}) ; 6.652(\mathrm{~d}, 2 \mathrm{H}, \mathrm{J}=2.6 \mathrm{~Hz}) ; 6.199(\mathrm{~d}, 2 \mathrm{H}, \mathrm{J}=2.6 \mathrm{~Hz}) ; 7.589-7.148(\mathrm{~m}, 14 \mathrm{H}$, Ar-H) $3.126(\mathrm{~s}, 3 \mathrm{H}) \mathrm{ppm}$. HRMS ((+)-ESI): $\mathrm{m} / \mathrm{z}=425.515$ (calculated: 425.524$)$.

\section{3-(1-(3,4-Dimethoxyphenyl)-4,5-diphenyl-1H-imidazol-2-yl)-1H-indole (2e)}

Colourless solid, Anal.: (Calcd): C (81.61\%), H (5.25\%), N (9.52\%), O (3.62\%), (Found): C (81.59\%), H (5.28\%), N (9.49\%), O (3.60\%). FTIR (KBr, cm-1): Vmax: 3400, 3060, 3036, 2980, 2950, 2930, 1618, 1600, 1580, 1543, 1493, 1450, 1445, 1409, 1390, 1250, 1195, 1032, 876, 790, 798, 768, 696. ${ }^{1} \mathrm{HNMR}$ (400 MHz, DMSO-d6): 11.843 (s, 1H, indole), 8.661 (s, 1H, Ar-H, Indole), 8.383 (d, 1H, $\mathrm{J}=8.00 \mathrm{~Hz}), 7.553(\mathrm{dd}, 1 \mathrm{H}, \mathrm{J}=2.4 \mathrm{~Hz}), 7.692(\mathrm{dd}, 1 \mathrm{H}, \mathrm{J}=7.65 \mathrm{~Hz}, 2.5 \mathrm{~Hz}), 7.761(\mathrm{~d}, 1 \mathrm{H}, \mathrm{J}=7.51 \mathrm{~Hz})$, 7.547-7.171 (m, 10H, Ar-H), 8.001 (s, 1H, Ar-H), 7.151 (d, 1H, Ar-H, J=6.95 Hz), 7.103 (d, 1H, Ar$\mathrm{H}, \mathrm{J}=6.92 \mathrm{~Hz}), 3.852(\mathrm{~s}, 3 \mathrm{H}), 3.753$ (s, 3H) ppm. HRMS ((+)-ESI): $\mathrm{m} / \mathrm{z}=473.50$ (calculated: 473.56). 
2-(1H-Indol-3-yl)-4,5-diphenyl-1H-imidazol-1-ol (2f)

Colourless solid, Anal.: (Calcd): C (78.61\%), H (4.88\%), N (11.96\%), O (4.55\%), (Found): C (78.63\%), H (4.86\%), N (11.99\%), O (4.52\%). FTIR (KBr, cm-1): Vmax: 3645, 3386, 3157, 3050, 3015, 2891, 2837, 2010, 1675, 1641, 1619, 1596, 1580, 1521, 1448, 1414, 1341, 1227, 1099, 867, 705, 747, 692, 635. ${ }^{1} \mathrm{HNMR}$ (400 MHz, DMSO-d6): 11.840 (s, O-H), 11.205 (s, 1H, indole), 8.225 (s, 1H, Ar-H, Indole), $7.865(\mathrm{~d}, 1 \mathrm{H}, \mathrm{J}=7.1 \mathrm{~Hz}), 7.105(\mathrm{dd}, 1 \mathrm{H}, \mathrm{J}=7.1 \mathrm{~Hz}), 7.120(\mathrm{dd}, 1 \mathrm{H}, \mathrm{J}=7.4 \mathrm{~Hz}), 7.613(\mathrm{~d}, 1 \mathrm{H}$, $\mathrm{J}=7.4 \mathrm{~Hz}), 7.535-7.165$ (m, 10H, Ar-H) ppm. HRMS ((+)-ESI): $\mathrm{m} / \mathrm{z}=351.90$ (calculated: 351.40 ).

\section{2-[2-(1H-Indol-3-yl)-4,5-diphenyl-1H-imidazol-1-yl]ethan-1-ol (2g)}

Colourless solid, Anal.: (Calcd): C (79.13\%), H (5.58\%), N (11.07\%), O (4.22\%), (Found): C (79.09\%), H (5.62\%), N (11.05\%), O (4.18\%). FTIR (KBr, $\left.\mathrm{cm}^{-1}\right)$ : Vmax: 3644, 3386, 3157, 3050, 3014, 2893 , 2839, 1987, 1675, 1634, 1619, 1597, 1581, 1521, 1448, 1493, 1414, 1340, 1026, 1227, 950, 931, 906, 869, 706, 747, 691, 635. ${ }^{1} \mathrm{H}$ NMR (400 MHz, DMSO-d6): 12.132 (s, O-H), 11.517 (s, 1H, indole), 8.272 (s, 1H, Ar-H, Indole), 8.099 (d, 1H, J=7.2 Hz), 7.351 (dd, 1H, J=7.1 Hz), 7.650 (dd, 1H, J=7.4 $\mathrm{Hz}), 7.896$ (d, 1H, J=7.4 Hz), 7.557-7.449 (m, 10H, Ar-H), 4.034 (t, 2H, J=6.6 Hz) 3.393 (dd, 2H, $\left.\mathrm{J}_{1}=12.3, \mathrm{~J}_{2}=6.5 \mathrm{~Hz}\right)$ ppm. HRMS $((+)-\mathrm{ESI}): \mathrm{m} / \mathrm{z}=379.90$ (calculated: 379.45 ).

\section{2-[2-(1H-Indol-3-yl)-4,5-diphenyl-1H-imidazol-1-yl]hexan-1-ol (2h)}

Colourless solid, Anal.: (Calcd): C (79.97\%), H (6.71\%), N (9.65\%), O 3.67\%), (Found): C (79.99\%), H (6.74\%), N (9.62\%), O (3.63\%). FTIR (KBr, $\left.\mathrm{cm}^{-1}\right)$ : Vmax: 3688, 3387, 3138, 3111, 3057, 2976, 2926, 2855, 1967, 1634, 1600, 1580, 1520, 1500, 1460, 1485, 1440, 1444, 1340, 1241, 1073, 951, 931, 877, 716, 749, 696, 641. ${ }^{1} \mathrm{HNMR}$ (400 MHz, DMSO-d6): 14.956 (s, brs, O-H), 12.463 (s, 1H, indole), 8.100 (s, 1H, Ar-H, Indole), 7.938 (d, 1H, J=7.2 Hz), 7.220 (dd, 1H, J=7.5 Hz), 7.292 (dd, 1H, J=7.5 $\mathrm{Hz}$ ), 7.786 (d, 1H, J=7.5 Hz), 7.545-7.328 (m, 10H, Ar-H), 4.357 (t, 2H, J=7.1 Hz), 3.870 (t, 2H, J=6.5 $\mathrm{Hz}), 1.34(\mathrm{~m}, 2 \mathrm{H}), 0.933(\mathrm{~m}, 2 \mathrm{H}), 0.404(\mathrm{~m}, 2 \mathrm{H}) \mathrm{ppm}$. HRMS $((+)-\mathrm{ESI}): \mathrm{m} / \mathrm{z}=435.00$ (calculated: 435.56).

\section{5-Bromo-3-(1,4,5-Triphenyl-1H-imidazol-2-yl)-1H-indole (3a)}

Colourless solid, Anal.: (Calcd): C (71.21\%), H (4.31\%), N (8.55\%), Br (16.55\%), (Found): C (71.031\%), H (4.11\%), N (8.57\%), Br (16.29\%). FTIR (KBr, $\left.\mathrm{cm}^{-1}\right): V \max : 3450,3055,3020,1650$, 1600, 1580, 1522, 1450, 1245, 1130, 780, 732, 765, 695, 580. ${ }^{1} \mathrm{HNMR}$ (400 MHz, DMSO-d6): 11.952 (s, 1H, indole), $8.535(\mathrm{~s}, 1 \mathrm{H}$, Ar-H, Indole), $8.421(\mathrm{~s}, 1 \mathrm{H}), 7.942 \quad(\mathrm{~d}, 1 \mathrm{H}, \mathrm{J}=7.71 \mathrm{~Hz}), 7.959(\mathrm{~d}, 1 \mathrm{H}$, $\mathrm{J}=7.56 \mathrm{~Hz}), 7.615-7.312$ (m, 15H, Ar-H) ppm. HRMS ((+)-ESI): $\mathrm{m} / \mathrm{z}=490.40$ (calculated: 490.39).

\section{5-Bromo-3-(1-(4-ethoxyphenyl)-4,5-diphenyl-1H-imidazol-2-yl)-1H-indole (2b)}

Colourless solid, Anal.: (Calcd): C (69.67\%), H (4.53\%), N (7.86\%), Br (14.95\%), O (2.99\%), (Found): C (67.65\%), H (4.50\%), N (7.89\%), Br (14.93\%) O (2.97\%). FTIR (KBr, $\left.\mathrm{cm}^{-1}\right): 3420,3105,3092$, 2950, 1630, 1602, 1590, 1540, 1490, 1465, 1394, 1407, 1250, 1243, 1195, 1123, 815, 775, 760, 692, 580. Vmax: ${ }^{1} \mathrm{HNMR}$ (400 MHz, DMSO-d6):12.124 (s, 1H, indole), 8.492 (s, 1H, Ar-H, Indole), 8.451 $(\mathrm{s}, 1 \mathrm{H}), 7.937(\mathrm{~d}, 1 \mathrm{H}, \mathrm{J}=7.48 \mathrm{~Hz}), 7.961(\mathrm{~d}, 1 \mathrm{H}, \mathrm{J}=7.51 \mathrm{~Hz}), 7.627-7.216(\mathrm{~m}, 10 \mathrm{H}$, Ar-H), $7.832(\mathrm{~d}, 2 \mathrm{H}$, $\mathrm{J}=7.58 \mathrm{~Hz}), 7.080(\mathrm{~d}, 2 \mathrm{H}, \mathrm{J}=8.41 \mathrm{~Hz}), 3.95-2.90(\mathrm{q}, 2 \mathrm{H}, \mathrm{J}=7.05 \mathrm{~Hz}), 1.391(\mathrm{t}, 2 \mathrm{H}, \mathrm{J}=6.99 \mathrm{~Hz}) \mathrm{ppm}$. HRMS ((+)-ESI): $\mathrm{m} / \mathrm{z}=536.48$ (calculated: 536.46$)$.

\section{References}

[1] Nirwan N., Pareek C., and Swami V. K. (2020) Indolylimidazoles: Synthetic approaches and biological activities. Current Chem. Lett., 9 (1) 31-50.

[2] Kawasaki I., Katsuma H., Nakayama Y., Yamashita M., and Ohta S. (1998) Total Synthesis of Topsentin, Antiviral and Antitumor Bis(indolyl)imidazole. Heterocycles, 48 (9) 1887-1901.

[3] Burres N. S., Barber D. A., Gunasekera S. P., Shen L. L., and Clement J. J. (1991) Antitumor activity and biochemical effects of Topsentin. Biochem. Pharmacol., 42 (4) 745-751. 
[4] Bartik K., Braekman J. C., Daloze D., Stoller C., Huysecom J., Vandevyver G., and Otringer R. (1987) Topsentins, new toxic bis-indole alkaloids from the marine sponge Topsentia genitrix. Can. J. Chem., 65 (9) 2118-2121.

[5] Morris S. A., and Andersen R. J. (1990) Brominated bis(indole) alkaloids from the marine sponge hexadella SP. Tetrahedron, 46 (3)715-720.

[6] Bao B., Sun Q., Yao X., Hong J., Lee C. O., Sim C. J., Im K. S., and Jung J. H. (2005) Cytotoxic bisindole alkaloids from a marine sponge Spongosorites sp. J. Nat. Prod., 68 (5) 711-715.

[7] Tsujii S., Rinehart K. L., Gunasekera S. P., Kashman Y., Cross S. S., Lui M. S., Pomponi S. A., and Diaz M. C. (1998) Topsentin, bromo topsentin, and dihydroxy bromo topsentin: antiviral and antitumor bis(indolyl) imidazoles from Caribbean deep-sea sponges of the family Halichondriidae, Structural and synthetic studies. J. of Org. Chem., 53 (23) 5446-5453.

[8] Shin J., Seo Y., Cho K. W., Rho J. R., and Sim C. J. (1999) New bis(indole) alkaloids of the topsentin class from the sponge Spongosorites genitrix. J. Nat. Prod., 62 (4) 647-649.

[9] Casapullo G., Bifulco I., Bruno R., and Riccio (2000) New bisindole alkaloids of the topsentin and hamacanthin classes from the Mediterranean marine sponge Rhaphisia lacazei. J. Nat. Prod., 63 (4) $447-451$.

[10] McConnell O. J., Saucy G., and Jacobs R. (1994). US Patent 5,290,777.

[11] Wright A. E., Pomponi S. A., and Roberts J. A. (1999). Patent WO 9,942,092.

[12] Sakemi S., and Sun H. H. (1991) Nortopsentins A, B, and C. Cytotoxic and Antifungal Imidazolediylbis[indoles] from the Sponge Spongoaorites ruetzleri. J. Org. Chem., 56 (13) 4304-4307.

[13] Alvarado S., Roberts B. F., Wright A. E., and Chakrabarti D. (2013) The bis(Indolyl)imidazole alkaloid nortopsentin a exhibits antiplasmodial activity. Antimicrob. Agents Chemother., 57 (5) 2362-2364.

[14] Sun H. H., Sakemi S., Gunasekera S., Kashman Y., Lui M., Burres N., and McCarthy P. (1919) US Patent 4,970,226. Chem. Abstr. $11535701 \mathrm{z}$.

[15] Bewely C. A, and Faulkner D. J. (1998) Lithistid sponges: Star performers or hosts to the stars. Angewandte Chem. International Ed. in Eng., 37 (16) 2162-2178.

[16] Cohen J., Paul G. K., Gunasekera S. P., Longley R. E., and Pomponi S. A. (2004) 6-Hydroxydiscodermindole, a new discodermindole from the marine sponge Discodermia polydiscus. Pharm. Biol., 42 (1) 59-61.

[17] Hogan I. T., and Sainsbury M. (1984) The synthesis of dendrodoine, 5-[3-(N,N-dimethylamino- 1,2,4thiadiazolyl]-3-indolylmethanone, a metabolite of the marine tunicate dendroda grossular. Tetrahedron, 40 (4) 681-682.

[18] Capon R. J., Peng C., and Dooms C. (2008) Trachycladindoles A-G: Cytotoxic heterocycles from an Australian marine sponge, Trachycladus laevispirulifer. Org. Biomol. Chem., 6 (15) 2765-2771.

[19] Sato H., Tsuda M., Watanabe K., and Kobayashi J. (1998) Rhopaladins A D, new indole alkaloids from marine tunicate Rhopalaea sp. Tetrahedron, 54 (30) 8687-8690.

[20] Hlasta D. J. (1991) US patent 5,017,584. Chem. Abstr. (1991) 115, 232,249.

[21] Karabelas K., Lepisto M., and Sjo P. (2000) Word patent WO 2,000,078,750. Chem. Abstr. (2000) 13, 471,594.

[22] Karabelas K., Lepisto M., and Sjo P. (1999) Word patent WO 9,932,483. Chem. Abstr. (1999) 13, $158,823$.

[23] Levy L. (1977) Proceedings, Soc. Exp. Biol. Med., 153 34-36. Chem. Abstr. (1977) 86,25,978.

[24] Hoff D. R. DE. (1970) 1,962,822, Chem. Abstr. (1970) 7,387,931.

[25] Doemling A., and Beck B. (2001) Word patent WO 2001,025,213. Chem. Abstr. (2001) 134,295,819.

[26] Reddy Y. T., Sekhar K. R., Sasi N., Reddy P. N., Freeman M. L., and Crooks P.A. (2010) Novel substituted (Z)-5-((N-benzyl-1H-indol-3-yl)methylene)imidazolidine-2,4-diones and 5-((N-benzyl-1H-indol-3yl)methylene)pyrimidine-2,4,6(1H,3H,5H)-triones as potent radio-sensitizing agents. Bioorganic Med. Chem. Lett., 20 (2) 600-602.

[27] Roffey J. R. A. (1996) PhD thesis, Loughborough University, UK.

[28] Zoraghi R., Worrall L., See R. H., Strangman W., Popplewell W. L., Gong H., Samaai T., Swayze R. D., Kaur S., Vuckovic M., Finlay B. B., Brunham R. C., McMaster W. R., Davies-Coleman M. T., Strynadka N. C., Andersen R. J., and Reiner N. E. (2011) Methicillin-resistant Staphylococcus aureus (MRSA) pyruvate kinase as a target for bis-indole alkaloids with antibacterial activities. J. Biol. Chem. 286 (52) 44716-44725.

[29] Hilya V. P., Grishko L. G., Golubushina G. M., Arkhipova N. N., and Turov A. V. (1994) Khim. Geterotsikl. Soedin., 1063-1070. Chem. Abstr. (1995) 122, 314495.

[30] Mahmoodi N.O., Nikokar I., Farhadi M., and Ghavidast A. (2014) One-pot multicomponent synthesis of mono- and bis-indolylimidazole derivatives using Zn ${ }^{2+} @ \mathrm{KSF}$ and their antibacterial activity. Zeitschrift Fur Naturforsch. Sect. B J. Chem. Sci., 69 (6) 715-720.

[31] Pareek C., Pareek D., Nirwan N., and Jain A. (2018) An Efficient Combinatorial Approach for Beta-Lactam Antibiotics with Novel Adjuvants against Gram-Negative Organisms to Combat Multi-Drug Resistance. Int. Acade. Con. Appl. Res. Eng. Sci. Tech., Brussels, Belgium. Diamond Scientific Publication: Lithuania, 134143. 
[32] Rajaraman D., Sundararajan G., Loganath N. K., and Krishnasamy K. (2017) Synthesis, molecular structure, DFT studies and antimicrobial activities of some novel 3-(1-(3,4-dimethoxyphenethyl)-4,5-diphenyl-1Himidazol-2-yl)-1H-indole derivatives and its molecular docking studies. J. Mol. Struct., 1127 597-610.

[33] Benkli K., Demirayak S., Gundogdu-Karaburun N., Kiraz N., Iscan G., and Ucucu U. (2004) Synthesis and antimicrobial activities of some imidazole substituted indoles. Indian J. Chem. - Sect. B Org. Med. Chem., 43 (1) 174-179.

[34] Naureen S., Ijaz F., Munawar M. A., Asif N., Chaudhry F., Ashraf M., and Khan M. A. (2017) Synthesis of tetrasubstituted imidazoles containing indole and their anti urease and antioxidant activities. J. Chil. Chem. Soc., 62 (3) 3583-3587.

[35] Singh P., and Kumar R. (2015) Synthesis and Evaluation of Antioxidant Activity of 2,4,5-Triaryl Imidazole. Clin. Med. Biochem., Open Access. 01 (1) 2-5.

[36] Kobori T., Hatanaka Y., Ohjta T., and Nakanishi M. (1999) JP patent 11,199,583. Chem. Abstr. (1999) 13,197,623.

[37] Ota T., Nakanishi M., Tomisawa K., and Kobori T. (1999) Word patent WO, 9,935,142. Chem. Abstr. (1999) 13,173,652.

[38] Ohta T., Nakanishi M., Tomizawa K., and Kobori T. (1999) JP patent 11,228,570. Chem. Abstr. (1999) $131,170,350$.

[39] Ota T., Nakanishi M., Tomisawa K., and Kobori T. (1999) JP patent 11,228,572. Chem. Abstr. (1999) $131,170,351$.

[40] Biradar J. S., Mugali P. S., Sasidhar B. S., and Parveen R. (2008) One-pot synthesis of substituted imidazoles containing indole and their antimicrobial activities. Org. Chem. An Indian J. 4 (4-6) 408-411. Chem Abstr., (2009), 15,237,464.

[41] Fresneda P. M., Molina P., and Sanz M. A. (2001) Microwave-assisted regioselective synthesis of 2,4disubstituted imidazoles: Nortopsentin D synthesized by minimal effort. Synlett., (2) 218-221.

[42] Velsicol Chemical Corp. (1975) USA NL patent 7317578. Chem. Abstr. (1975) 84,164,785.

[43] Biradar J. S., Somappa S. B., and Mugali P. S. (2012) One-pot, solvent-free synthesis of 2,5-disubstituted indolyl imidazoles by microwave irradiation. Der pharma chemical., 4 (1) 437-441.

[44] Nikoofar K., and Dizgarani S. M. (2017) HNO3@nano SiO2: An efficient catalytic system for the synthesis of multi-substituted imidazoles under solvent-free conditions, J. Saudi Chem. Soc., 21 (7) 787-794.

[45] Papaioannou C. G. (1972) US patent 3673208. Chem. Abstr. (1972) 7,788,507.

[46] Shaterian H. R., Ranjbar M., and Azizi K. (2011) Synthesis of highly substituted imidazoles using Brønsted acidic ionic liquid, triphenyl(propyl-3-sulphonyl)phosphonium toluenesulfonate, as a reusable catalyst. $J$. Iran. Chem. Soc., 8 (4) 1120-1134.

[47] Molina P., Fresneda P. M., Sanz M. A., Foces-Foces C., and Ramirez de Arellano M. C. (1998) Investigative Studies on the Formation of the Imidazo. Tetrahedron, 54 9623-9638.

[48] Kobori T., Hatanaka Y., Ota T., and Nakanish M.. (1999) JP patent 11,199,582. Chem. Abstr. (1999) $13,197,622$.

[49] Pandit S., Bhalerao S. K., Adhav G. L., and Pandit V. U. (2011) Amberlyst A-15: Reusable catalyst for the synthesis of 2,4,5-trisubstituted and 1,2,4,5-tetrasubstituted-1H-imidazoles under MW irradiation. J. of Chemical Sciences, 123 (4) 421-426.

[50] Nirwan N., Pareek C., and Mosalpuri S. R. (2015) Proceeding of India-Japan Bilateral Conference on Applied Science for Advancement of Research and Industrialization (20-27 Sept. 2015, Jaipur, India), BICON, Jaipur, India, 2, 129-132.

[51] Nirwan N., and Pareek C. (2017) Synthesis of 2,4,5-trisubstituted imidazole and 4,5- disubstituted indolylimidazole derivatives by using Amberlyst A-15 as a green, recyclable catalyst. International J. of Scie. Res.in Sci. and Tech, 3 76-82.

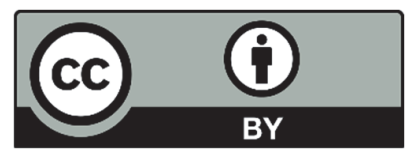

(C) 2021 by the authors; licensee Growing Science, Canada. This is an open access article distributed under the terms and conditions of the Creative Commons Attribution (CC-BY) license (http://creativecommons.org/licenses/by/4.0/). 